
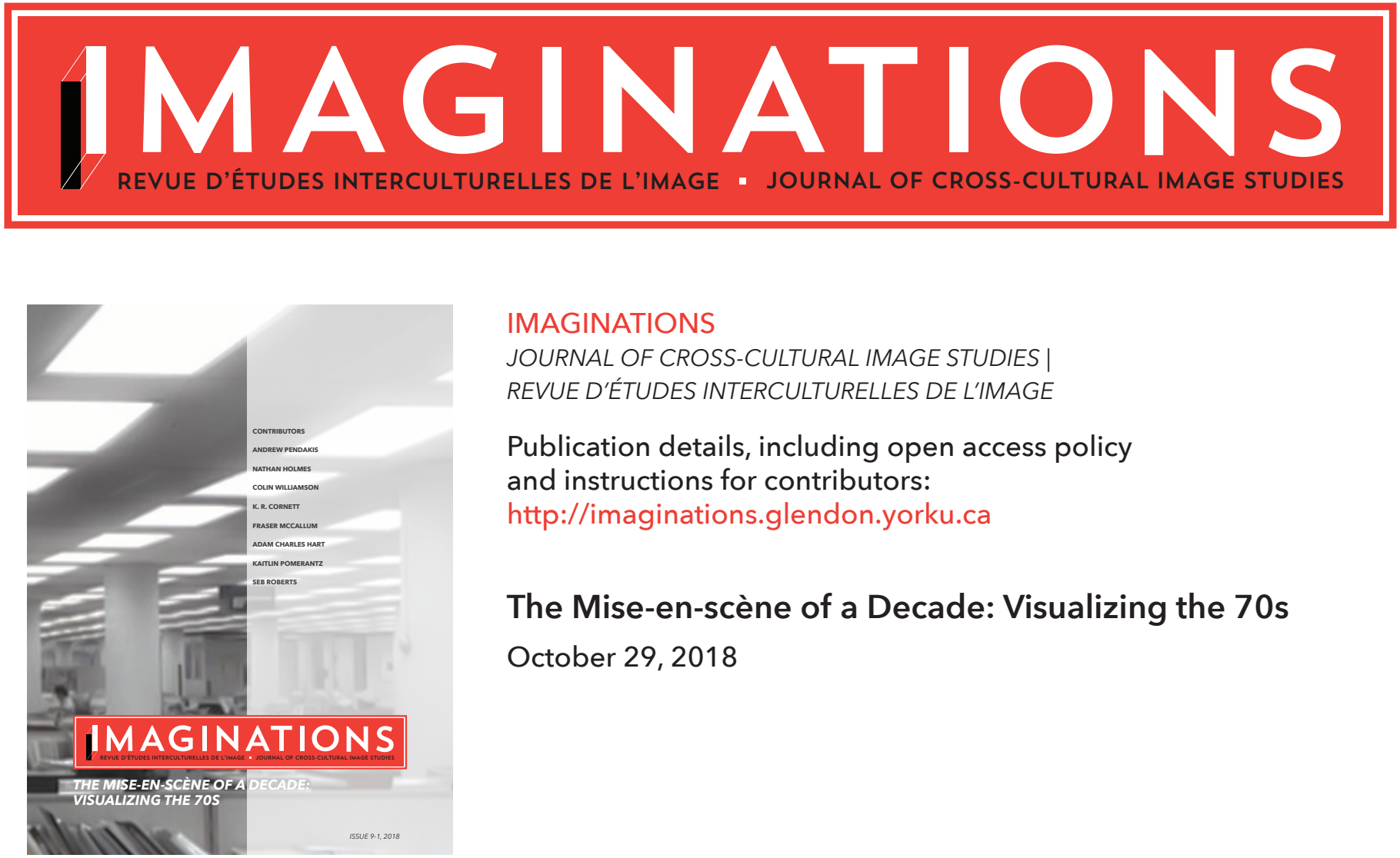

IMAGINATIONS
JOURNAL OF CROSS-CULTURAL IMAGE STUDIES |
REVUE D'ÉTUDES INTERCULTURELLES DE L'IMAGE

Publication details, including open access policy and instructions for contributors:

http://imaginations.glendon.yorku.ca

The Mise-en-scène of a Decade: Visualizing the 70s

October 29, 2018

To cite this article:

Roberts, Seb. "Strange Vices: Transgression and the Production of Difference in the Giallo." Imaginations, vol. 9, no. 1, 2018: Web (date accessed), pp. 115-131. DOI 10.17742/IMAGE.p70s.9.1.9.

To link to this article:

http://dx.doi.org/10.17742/IMAGE.p70s.9.1.9

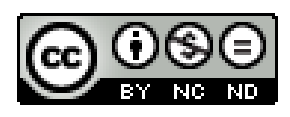

The copyright for each article belongs to the author and has been published in this journal under a Creative Commons Attribution NonCommercial NoDerivatives 3.0 license that allows others to share for non-commercial purposes the work with an acknowledgement of the work's authorship and initial publication in this journal. The content of this article represents the author's original work and any third-party content, either image or text, has been included under the Fair Dealing exception in the Canadian Copyright Act, or the author has provided the required publication permissions. 


\title{
STRANGE VICES: TRANSGRESSION AND THE PRODUCTION OF DIFFERENCE IN THE GIALLO
}

\author{
SEB ROBERTS
}

\begin{abstract}
The giallo, an Italian genre of horror film that peaked in the 1970s, is infamous for peddling shock and slaughter. Under the graphic sex and violence, however, the giallo expresses popular anxiety surrounding the transgression of social and sexual norms in modern Italy. Superficial$l y$, the giallo seems to suggest that social and cultural turmoil necessarily produces death. Yet the giallo foregrounds the obvious excitement and attraction of transgression, allowing that transgression could in fact be generative of positive, invigorating difference.

Résumé | Le giallo, un genre de film d'horreur italien qui a connu son heure de gloire dans les années 70 , a la réputation de mélanger choc et massacre. Sous l'aspect pornographique et violent, toutefois, le giallo exrime l'anxiété populaire qui entoure la transgression des normes sociales et sexuelles dans l'Italie moderne. En surface, le giallo semble suggérer que lagitation sociale et culturelle conduit nécessairement à la mort. Cependant en mettant en avant l'excitation et l'attrait évidents de la transgression, le giallo permet à cette transgression dêtre porteuse de différences positives et tonifiantes. Mots-clé: giallo, transgression, mondernité, violence contre les fermmes, cinéma d'horreur.
\end{abstract}

7 he giallo was a particularly fleshy style of horror film from Italy that began in the early 1960 s and flourished during the 1970s: a blood-soaked spectacle identified with cheap thrills and frequently low production values. Despite this, the giallo was shrewdly perceptive in its projections of social anxieties during the most violent decade of Italy's postwar history. In transgression, the giallo saw thrilling possibility and dangerous disorder, and in hegemony, stability and suffocation. These films largely regarded the upheaval of modernity with ambivalence while nevertheless generating much of its diegetic tensions from the instability of social norms-particularly those surrounding gender. Trafficking in sleaze, shock, and slaughter, the giallo appeared to argue that the volatility of modern life necessarily produces death. However, this impression is but a first glance. A more incisive examination of how the giallo presents transgression as a production of difference reveals a different understanding of social turmoil: as a generative force to be embraced. 


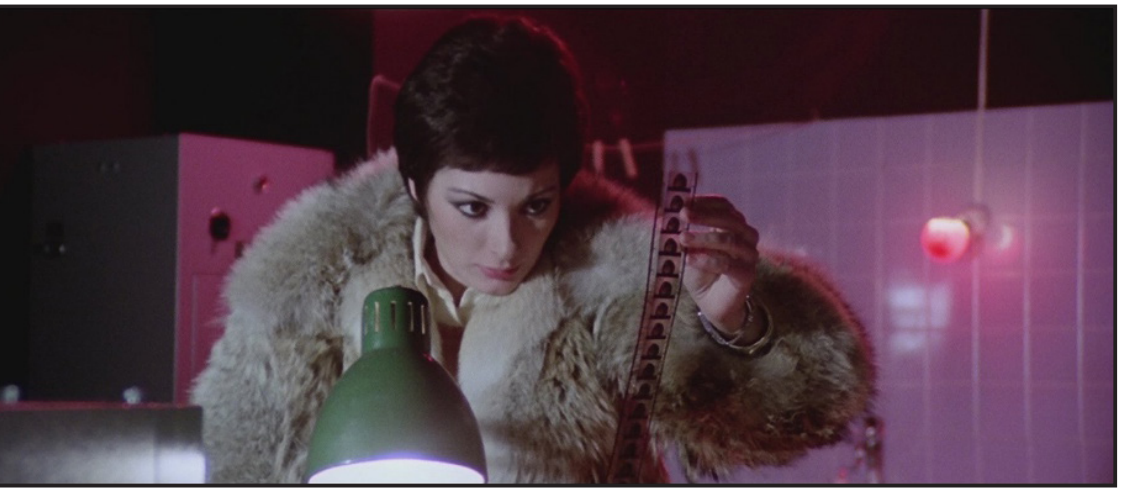

Fig. 1

The giallo is not simply a horror film that happens to have been made in Italy. It is a cinematic filone, expressed through a constellation of tropes, including (but by no means limited to): a black-gloved killer, pursued by an amateur detective; women undressed and in distress; a backdrop of jet-setting bourgeois mobility; skronky free jazz or pulsating prog rock; and ubiquitous bottles of J\&B whisky. ${ }^{1,2}$ Yet the most recognizable-arguably, the definitivefeature of the giallo is the excessively savage and sensational murder scene, a scene whose bloody sadism is often matched only by its bizarre inventiveness. The giallo murder scene is an irruption of spectacle that forgoes classical notions of narrative necessity, characterization, and even visual coherency (Totaro 163), giving filmmakers a chance to experiment and indulge their wildest creative urges. Including serrated shadows, off-kilter framing, slow motion, first-person perspective, extreme zooms, impressionistic editing, cacophonous music, and ghoulish sound effects, a broad variety of available techniques are employed to heighten the shock and awe of a giallo murder. In these scenes, when the filmmakers abandon naturalism in pursuit of visceral charge, the giallo approaches a kind of affective ecstasy. These moments of frenzied sensation not only connect the giallo to cinema's pre-grammatical roots as a popular attraction (Gunning 738; Wagstaff 48), but they also constitute, according to Pier Paolo Pasolini, "the dominant artistic nature of cinema, its expressive violence, its oneiric physical quality" (172).

Such apparent privileging of spectacle over coherent narrative and characterization has earned the giallo a degree of critical disdain. Anthony Mann claims the outbursts of extreme sex and violence "reveal the director's fear that the audiences get bored" (qtd. in Wagstaff 245), comparing the erratic rhythms of the films to the "electrocardiogram for a clinic case" (qtd. in Wagstaff 245). This mistrust of the spectator's focus may have been true in certain cases: director Umberto Lenzi once lamented that prosaic exposition "distracts the audience's attention" (68), suggesting that "the spectator prefers spectacular events to turgid screenplay" (68). However, there is also a historical and economic basis in Italy for films that eschew classical formalism in favour of fitful spectacle. Christopher Wagstaff notes that, "[s] ince the Second World War, the Italian exhibition sector had grown accustomed to having too many cinemas and too many films in circulation at any one time" (249), causing "a relatively low level of exploitation of a relatively large number of films" (249). This meant shorter initial theatrical runs, and thus a film's earnings depended largely upon where-that is, to what market-it was exhibited. To ensure that they could "repay their large production costs before interest payments [ate] away into revenue" (Wagstaff 247), films with bigger budgets and financial backing would typically be screened in first-run theatres, known as prima visione: urban cinema palaces that drew from a broader pool of potential spectators and could therefore command significantly larger ticket 
prices. $^{3}$ Less prestigious pictures with smaller production, marketing, and distribution budgets were often relegated to terza visione, thirdrun theatres with depressed ticket prices commonly found in peripheral and rural areas. ${ }^{4}$

At every tier of the exhibition sector, the surfeit of screens and high turnover in programmes required a steady stream of film product to keep customers coming back. Therefore, Wagstaff argues, "the whole structure [of the Italian film industry] depended on repetition. The audience had to return to the same cinema the next day. It had to be offered something different but providing the same gratifications. In other words, a repetition with variation" (254). For this reason, postwar Italian cinema has been characterized by formulaic cycles, called filone, wherein a single box-office smash could unleash a torrent of imitations. Targeting prima visione and terza visione audiences alike and churned out at an industrial pace, the filone typified whatever trend promised the easiest money at that moment, whether it was farcical comedies, sword-and-sandal epics, spaghetti westerns, or ersatz James Bond capers (Frayling 70-71).

The "repetition with variation" of filone required that filmmakers rely upon not only homologous themes, narratives, and characters, but specific techniques and devices that would reliably gratify the audience. Wagstaff claims that the three most sought-after audience responses, in the form of "physiological reactions" (253), were "laughter, thrill, titillation...provoked not by whole films, but by items or moments in films. Italian formula cinema simply juggled with plot items to produce the required recipe that would stimulate the appropriate number and kind of these 'physiological' responses"' (253). Hence the "electrocardiogram" rhythm of Italian popular cinema: the film as a unitary work was less important in gratifying the audience (thereby creating repeat customers) than intermittent eruptions of excess, shock, surprise, and spectacle.

Thus, the specific attraction of the giallo lies precisely in its hyper-stylized and grotesque depictions of sex and death. To bemoan the giallo's lack of fluid pacing, scrupulous plotting, naturalistic acting, and so on, is to miss the point. Consider Jonathan Rosenbaum's review of Sergio Martino's Torso, a.k.a. I corpi presentano tracce di violenza carnale (1973):

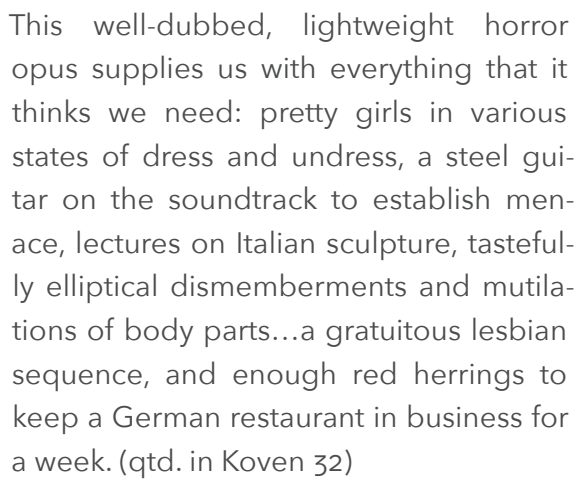

Rosenbaum astutely surmises that sex and violence are not excesses to distract from the film's technical or intellectual shortcomings-they are exactly what the film thinks we need. According to conventional critical criteria, Mikel J. Koven reminds us, "the assumption is that visual style (luscious photography, kinky sex, close-ups, etc.) is a device that covers up the holes in the narrative" (31, original emphasis), when in fact "narrative functions as merely the framework on which hang the spectacle sequences of violence, sex, and graphic gore" (38).

As with other filone, the giallo scaffolds its shocks with a familiar stock of character types, 


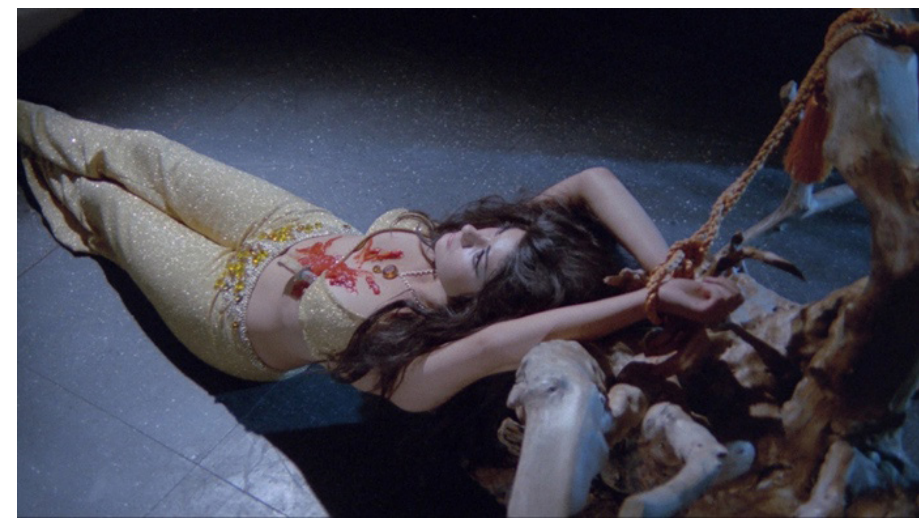

Fig. 2

antagonisms, and themes. However, there is an ideological conservatism undergirding the character types common to the giallo who set the plot-and so the succession of death-in motion: the debased countercultural youth; the innately suspicious Other; the psychotic sexual maladaptive; and the hysteric and/or monstrous female, among others. That is, in the gial$l o$, those characters who embody and perform non-traditional moral and social practices not only threaten hegemony, but their very presence also initiates a chain of transgression that inexorably leads to death. Certain gialli could be read as counter-hegemonic because the killer is revealed to be a figure of traditional authority (e.g. a priest, a doctor, or a wealthy businessman), symptomatic of a fundamental sickness or corruption at the core of the social order. Yet there are far more examples of films that depict bloodthirsty hippies, sexual deviancy, drug-induced psychosis, and the erosion of traditional morality as tragedy. The characters play with and transgress social norms by experimenting with travel, drugs, and sex, and each transgression, no matter how minor at first, releases a sequence of escalating effects that inevitably ends in murder. The lesson is that death is the final price of transgression, and the giallo killer is this price embodied. Only the death of the killer themselves at the film's climax promises to restore hegemonic order.

The threat to social order posed by violence was not an abstract concern for many Italians in the 1970s: it was daily life. The era between 1969 and 1983, known as the anni di piombo or "years of lead," witnessed over 14,000 acts of domestic terrorism, "resulting in 374 deaths and more than 1,170 injuries" (Glynn 3). While left-wing militants were responsible for numerous targeted assaults, kidnappings, and murders, the deadliest attacks were committed by the right, who adopted the practice of "indiscriminate bombings of public spaces tactically designed to cause maximum injury and panic" (Glynn 3). The logic behind the bombings was the strategia della tensione, or "strategy of tension." "The term," Alan O'Leary explains, "refers to the clandestine attempt to bring about an authoritarian Italy by fomenting a lawlessness which could then be blamed on communism and the weak democratic state, in turn justifying a military coup" (85). Accordingly, the right was assisted covertly by the Italian secret service and armed forces (Glynn 3; O'Leary 85).

Beyond the bloodshed and intrigue of the anni di piombo, the 1970s were generally tumultuous for Italy. The country was rapidly transitioning from an industrial to a service-oriented economy, thanks in part to surpassing Germany as Europe's top recipient of immigrants. These developments accelerated the unprecedented growth of Italy's urban centres and their suburbs. As Italy's ethnic and religious makeup was changing, so too were its relational structures and their undergirding value systems. The self-sufficient 
family bound by kinship and Catholicism retreated, displaced by the enlightened Cartesian subject qua individual consumer. Parochialism gave way to dividuated pluralism, and once-concrete hierarchies became fluid. In this sense, Italy's social and political turmoil was cause for a certain optimism: as Anna Cento Bull and Adalgisa Giorgio assert, "previously marginalized social groups raised their voices and demanded better representation, in the face of a society with politics which were fundamentally authoritarian and hierarchical" (qtd. in Glynn 5). Paradoxically, the insecurity and chaos of life in the Italian city could be "celebrated as evidence of interesting times, of the city's vitality" (O'Leary 246).

This ambiguous limen, between cosmopolitanism and chaos, is the space where many gialli set their stories. The films exploit and amplify the excitement and anxiety produced by the collision of difference. The most conspicuous flint for this friction is travel: some films change their geographic setting over the course of the movie (Death Walks on High Heels, 1971; The Strange Vice of Mrs Wardh, 1971); others follow Italians abroad (The Man with Icy Eyes, 1971; Short Night of the Glass Dolls, 1971); still others follow foreign travellers in Italy (The Girl Who Knew Too Much, 1963; The Bird with the Crystal Plumage, 1970). Yet otherness in the giallo is not limited to nationality. Even when a film is set in Italy with Italian characters, relational categories remain nebulous and in flux, as often exclusory as overlapping.

Such gradations of otherness are grippingly depicted in Lucio Fulci's Don't Torture a Duckling (1972). Set in the fictional southern Italian hamlet of Accendura, the film is an exemplar of what Xavier Mendik calls the "Mezzogiorno giallo" (391), a subset of gialli preoccupied with the economic and social disparities between the increasingly wealthy, industrialized, and urban(e) Italian North and the poor, rural South (known as the Mezzogiorno). The Mezzogiorno giallo, Mendik says, plays upon post-unification discourses wherein the South is degraded as the national backwater, "an 'untamed' landscape... where the environment and its inhabitants come to signify a monstrous mode of expression that must remain submerged within the civilized Northern consciousness" (400). ${ }^{5}$ The violence in Don't Torture a Duckling is the product of the clash between incompatible modes of existence, coded as the industrial North versus the rural South. Fulci himself affirms this perspective when he describes the film's opening shot as a pristine concrete highway "split[ing] the countryside like a gaping wound" (Fulci 59).

Consequent to the divergent regional fortunes of Italy's postwar economic miracle was a complementarily unequal distribution of modernization. Accordingly, the characters of Don't Torture a Duckling embody not only different socioeconomic strata but different epochs. Most deeply rooted in the archaic and arcane is La Maciara (played by Florinda Balkan), a reclusive Roma woman who performs black magic. Wary of her claims to occult powers, the townspeople prefer to avoid La Maciara, regarding her with a mix of contempt and fear. The local constabulary is only marginally less superstitious, in contrast to the hardnosed realism of the regional police commissioner (Virgilio Gazzolo), avatar of the modern Italian state. Observing and analysing the goings-on are the local priest Don Alberto (Marc Porel) and Roman journalist Andrea Martelli (Tomas Milian). Youthful and pragmatic, Don Alberto leverages popular interests (such as soccer) to appeal to his parish; nonetheless, he 
laments the corruption of traditional Christian morality by contemporary culture: "People aren't worried much about their immortal souls. They watch TV, go to the movies. They read the papers with all those scandalous photographs." Meanwhile, neoteric muckraker Martelli neither defends nor condemns the modern world, approaching it instead with a distinctly secular skepticism. He also has a roguish disregard for rules, entering people's homes through unlocked windows and withholding evidence from the police. The most thoroughly modern-and therefore transgressive-figure is $\mathrm{Pa}$ -

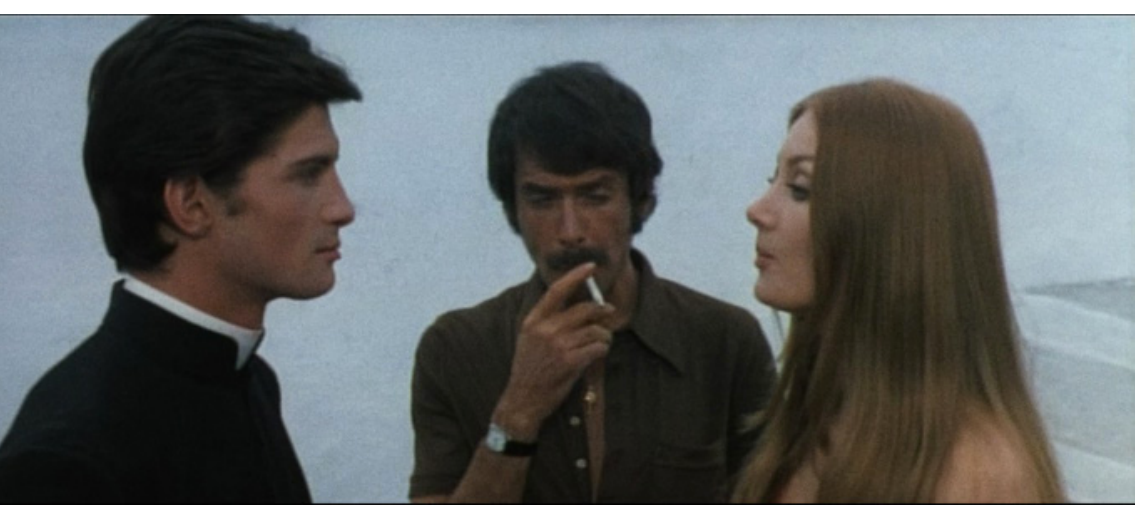

Fig. 3

trizia (Barbara Bouchet). Young, fashionable, and urbane, Patrizia lives in a chic high-modernist mansion, drives sports cars, and experiments with drugs. She is also sexually aggressive and a relentless flirt, and as such poses a direct threat to patriarchal order and, in Don Alberto's mind, to the innocence of Accendura's boys. The dramatis personae of Don't Torture a Duckling thus delineate a spectrum whereupon the otherness of one character to another is an articulation of their differential modernity.

Gialli are not usually so systematic in their representation of difference. Giuliano Carmineo's
The Case of the Bloody Iris (1972) primarily takes place in a single apartment tower block. Its occupants are a motley bunch drawn from all walks of life: a beautiful young model; a tall, dark, and handsome architect; an aged Jewish professor and his lesbian daughter; a prattling old crone with a cognitively impaired son; and a Black stripper. Such heterogenous neighbours suggest again that the modern Italian city is exciting, vital, and diverse, but that diversity also constitutes a threat. As the neighbours are bumped off one-by-one, suspicion falls upon everyone equally-after all, they are each different, ergo inscrutable and untrustworthy in their own way.

There is even difference within difference; that is, not all differences are equal. As represented in the giallo, some otherness is more or less threatening than other otherness. Tourists and foreigners are grudgingly tolerated: "They're coming and going all the time," grumbles journalist Andrea Bild (Franco Nero) in The Fifth Cord (1971), "from all over the world. It's like a hotel." Neurodivergent characters (such as Giuseppe in Don't Torture a Duckling) are commonly used as red herrings, presented as physically threatening but ultimately incapable of inflicting harm. Lesbians are tacitly approved of, the better to exploit what Laura Mulvey calls their "to-be-looked-at-ness" (19); after all, "it is a profoundly held tenet of film distributors that the spectator of a horror movie will almost invariably be male" (Jenks 154). Gay men appear frequently in gialli, but typically in "camp and effeminate roles for comic relief" (Koven 71). Transgendered characters fare the worst of all: in the rare instance that gialli address gender fluidity or transition, as in Four Flies on Grey Velvet (1971) or A Blade in the Dark (1983), it is only to provide a motivation-that of a "psychotic break" - for the killer. 
Sexual and gender differences are a perennial source of anxiety in gialli. They are a ready source of titillation for the filmmaker to exploit, but more importantly, sexual and gender differences initiate the chain of transgression discussed above: "transgression of body leads to transgression of behaviour and transgression of societal law" (Hallam 98), culminating in murder. This is true even of relatively milquetoast transgressions such as adultery or voyeurism, Koven contends, because they "weaken the socio-familial structure, and as a result of the weakening of those bonds, other more serious crimes often follow" (69). Accordingly, the more severe the initial transgression, the more swiftly it leads to death. A cheating spouse may trigger a chain of events that climaxes in murder, but more socially censured acts such as incest (In the Folds of the Flesh, 1970) or abortion (Strip Nude for Your Killer, 1975) appear to conjure the killer directly.

Because sexual transgression is a corporeal practice, it is among the most concrete and visually appreciable forms of transgression, but it is far from the only one. Gialli are fascinated by-and fascinate with-all forms of transgression: from the minor (playing music too loudly) to the major (spousal rape), from the abstruse (animal sacrifice) to the abominable (dismemberment). The legal ramifications of any given transgression are scarcely considered; indeed, the police are only sporadically present and often incompetent. ${ }^{6}$ Yet transgression qua crime, as a violent fissure in the social fabric, is omnipresent and inescapable. Gialli present an endless parade of adulterers, blackmailers, embezzlers, pederasts, rapists, thieves, and "sex maniacs," a term favoured in many a giallo. Moreover, a respectable upbringing, illustrious career, or estimable reputation is no guarantee of innocence. A wealthy debutante may be friends with stalkers and extortionists (A Lizard in a Woman's Skin, 1971); an acclaimed novelist may be a viciously abusive spouse (Your Vice is a Locked Room and Only I Have the Key, 1972); and a venerated surgeon may turn out to be a high-ranking member of a Satanic sex cult that performs human sacrifice (Short Night of the Glass Dolls, 1971). In gialli, no closet is without skeletons.

Of course, it is not literally the case that any and every transgression necessitates murder; that would be a "slippery slope" fallacy. Despite what Martino's All the Colors of the Dark (1972) depicts, having tea with a lesbian does not precipitate joining a demonic coven's blood orgies. But the implication is that it could. There may be many intermediary steps, each one a comparatively minor misbehaviour or crime, yet each step can be (and, in the giallo, is) taken. The horror of the giallo is in following the chain of transgression, as misbehaviour and crime compound until they achieve their ultimate expression in the ultimate transgression: murder. Unlike in monster movies or slasher films, the giallo killer is never an already-existing embodiment of inhuman evil; the giallo killer is an apparently "normal" human who becomes a killer-not because they are compelled by the devil, or possessed by some amorphous "evil," but because they choose to commit to murder.

This choice is manifest in the opportunism with which everyday objects are converted into weapons. It is uncommon that a giallo killer has a "signature" weapon, with notable exceptions such as the spiked gauntlet in Death Walks at Midnight (1972). Bladed weapons are by far the most popular in gialli, not the least because they are easily found within the miseen-scène: chef's knives, meat cleavers, switchblades, straight razors, letter openers, scalpels, 
axes, scissors, and so on. Strangulation is a close second; it can be performed with rope, a scarf, a shower curtain, a telephone line, or, in the absence of any other implements, by hand. Victims in gialli have been bludgeoned to death, drowned in bathtubs, thrown out windows, run over, chain-whipped, and worse. This grim inventory emphasizes that the giallo killer typically makes use of their environment and strikes when the opportunity presents itself, thereby demonstrating the choice to kill.

If any everyday object can be transformed into a lethal weapon, by the choice to use it as such, "then anyone can be a killer" (Koven 74) and, by extension, "anyone is a potential victim" (Freeland 187). The chain of transgression implies an unyielding drive towards murder, which can be committed using any ready-to-hand object; violence and death are immanent in the everyday, rendering the everyday itself as horrific. The effect, Koven submits, is feeling "that we are living in a veritable horror film ourselves" (74). The eruption of political violence that claimed hundreds of lives during the anni di piombo would thus seem like the logical-even necessary-extension of the moral fluctuations and eroding traditions of the 1960s and 1970s.

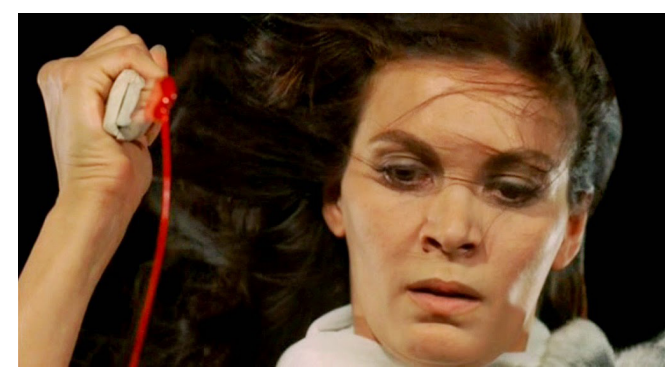

Fig. 4

Gialli rarely explicitly articulate the anxieties surrounding the social turmoil, economic instability, or political violence that convulsed
Italy: "the excesses and violence we see in giallo cinema," writes Koven, "are an impressionistic rendering of modernity" (61). What makes the giallo a unique expression of those anxieties is the figure upon whom it centres them: the female aggressor.

Given that the literary roots of the giallo are detective novels (Needham; Sevastakis 1; Wagstaff 2), the femme fatale of hard-boiled fiction and film noir is the obvious precursor of the giallo's female aggressor. However, there are also two antecedents native to Italian culture: the diva, representing " $[\mathrm{t}]$ he woman as predator, as the dominating figure, [with] the man in subjugation" (Shipman qtd. in Jenks 151); and the fattucchiera, or sorceress, embodiment and practitioner of "an alternative culture and...therefore a menace to a patriarchal society" (Bini 57). These three figures of a threatening femininity - the femme fatale, the diva, and the witch-were first synthesized in the character of Asa (played by Barbara Steele), villainess of Mario Bava's gothic horror film, $\mathrm{La}$ maschera del demonio (1960). Bava would return to the entanglement of death and the feminine in two subsequent films: The Girl Who Knew Too Much (1963) and Blood and Black Lace (1964), widely regarded as the prototypical gialli (Needham; Sevastakis 2; Koven 3-4) wherein, significantly, the killers are revealed to be women.

Throughout the filone, the female killer has been a prevalent feature of the giallo. So common are female killers that it rapidly became a "twist" ending to set up the expectation of a murderous woman, only to reveal that it was actually a man. Indeed, the audience can never be sure of the killer's gender before the climactic exposure of their identity. Female killers' motives are often the same as the males' (e.g. 
jealousy, greed, the aforementioned "psychotic break") and their methods no less brutal. Given that the giallo is predicated upon shock and horror, the filone's recurrent portrayals of female killers indicate that there was something disturbing about them beyond their motives and methods: the very fact that it was women committing these acts.

Among the assumptions and values that undergird patriarchy, Ruth Glynn calls particular attention to women's culturally assigned role as caregivers, homemakers, and custodians-that is, as defenders and guardians of society (11). Should a woman contradict this assumption in any way-by refusing to subordinate her needs to those of others, by pursuing her own pleasure, by exercising her authority in experimental, as opposed to conservative, ways-then her behaviour would be understood as fundamentally unnatural, a direct threat to social order.

During the 1970s, patriarchal values in Italy were facing unprecedented challenge. Alongside the student protests and labour unrest that exploded in the late 196os, the women's movement presented a dramatic rift in the social bedrock. At its most radical, the movement was a response to an "extra-parliamentary left [that] has not integrated women into its political perspective as an autonomous force, and is dominated by a male arrogance which Catholicism has promoted" (James 15). More broadly, the movement was an outgrowth of Italian women enjoying "unprecedented prosperity, industrialization, and modernization... . In short, there was a significant shift, even within the role of housewife, from submission and sacrifice to self-gratification, which, in turn, reflects a growing urge for self-expression" (Burke 211). Of course, if decoupled from consumption and in defiance of traditionally ordained roles, self-expression and social autonomy serve neither-indeed, work againstcapitalism and patriarchy, and as Silvia Federici notes, "in bourgeois morality, anything that is unproductive is obscene, unnatural, perverted" (24). The Italian women's movement flaunted this supposed unnaturalness and other-worldliness, as expressed in their most iconic slogan: "le streghe son tornate," or "the witches are back" (Bini 66).

The women's movement achieved two important legislative victories with the legalization of divorce in 1970 and abortion in 1978. Perhaps the best illustration of how radically women's place in society was changing is that, in the same decade, the percentage of female membership in left-wing militant groups was higher than in the Chamber of Deputies-by more than double (Glynn 6). Women were not only fighting for their rights-they were killing for them. Glynn describes the trauma of female-perpetrated violence in Italy as a "double wound" (11): the first is the physical wound itself, and the second is a psychic trauma rooted in the fact of having been attacked by someone considered beyond, or exclusory to, perpetrating violence. The phrase "double wound" derives from Glynn's reading of Sergio Lenci's autobiography, wherein he recalls being shot in the neck by a female militant. "A woman," Lenci writes, "wounds you twice with respect to a man" (qtd. in Glynn 31). Glynn remarks:

\footnotetext{
Lenci's account yields three key premises: that female perpetration has the traumatic valency of a double wound; that there is a long-established cultural correlation between masculinity and perpetration and between femininity and victimization; and, finally, that that correlation-that cultural resistance to an equation or even an
} 
association of women and violence-implicitly works to defeminize the violent woman. (136)

Therein lies the horror of the giallo's female aggressor: she refuses her role as social conservator; she refuses her role as victim; and she insists upon victimizing someone else. ${ }^{7}$ In these refusals and actions, she becomes something neither female nor male, in Lenci's own words, "incomprehensible" (qtd. in Glynn 31). Within the giallo, the detective's task is "one of uncovering, naming and containing otherness as something socially and morally threatening" (Needham), and that otherness, that social and moral threat is more often than not embodied by the female aggressor.

Granted, the audience will only perceive the female aggressor as inherently monstrous in accordance with patriarchal representations of gender: "screen males represent the Male and screen females the Female; ... this identification along gender lines authorizes impulses toward violence in males and encourages impulses towards victimization in females" (Clover 43). The presumption of the woman as victim, Federici argues, extends from the presumption of female sexual passivity: "Since we are expected to provide a release, we inevitably become the object onto which men discharge their repressed violence" (24). Conversely, the woman who demonstrates sexual agency and/ or physical dominance is abnormal, perverse, a violation of the natural order, unrepresentedergo unrepresentable-within the psychology of patriarchy. The sexually active (as opposed to passive) female logically precedes the female killer because the sexually active female imbricates that other thing unrepresentable within the patriarchal psyche: death (Cixous 885; Jenks 159).
Beyond the giallo's female aggressor, horror cinema in general disorders the tidy assignment of the role of victim or aggressor to a given gender. Carol J. Clover describes cinematic convention: " $\mathrm{t}$ ]o the extent that the possibility of cross-gender identification has been entertained, it has been that of the female with the male" (43) via the camera's capture of the male gaze. Yet in Clover's study of American horror cinema, the figure of the "final girl" enables the opposite cross-gender identification: that of the male audience with a female protagonist (Clover 43-46). In gialli, the female killer further extends and blurs the opportunities for cross-gender identification. Identifying with the sadistic pleasure of a female killer offers the male audience "a cathartic working through of the impossible contradictions between desire and the social dictates appropriate to gender" (Jenks 154). Simultaneously, the female audience is offered a violence of their own, identifying the female killer "not just as male projected horror but also as a consequence of women's rage, grounded in and justified by women's experience of violence and oppression" (Burke 198) under patriarchy.

The camerawork and editing in giallo murder scenes further destabilize identification with the characters onscreen. The camera typically adopts the first-person perspective of the approaching killer as the suspense crescendos. During the murder itself, the screen explodes in a flurry of edits: the screaming victim, the plunging blade, cloven skin, flailing hands, gushing blood, gaping eyes, and repeat. The cuts of the film mimic cuts into the victim's flesh, captured in the quasi-abstract detail of the extreme close-up. Identifiable perspectives disintegrate in an ecstasy of thrashing bodies. The audience experiences partial 
but simultaneous identification with killer and victim alike. For this reason, Patricia Pitsers argues:

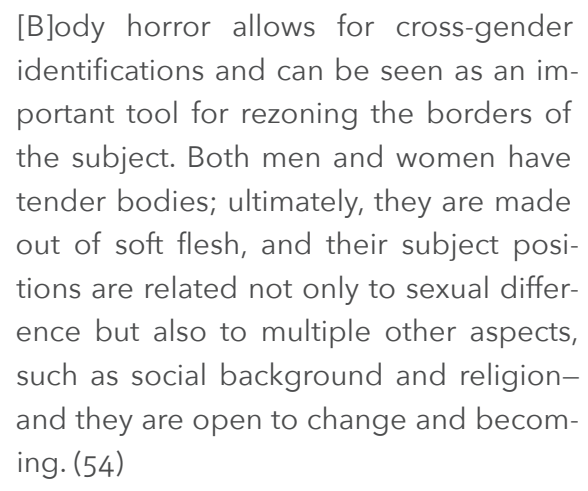

As the onscreen bodies transgress and are transgressed, and clear opposing perspectives dissolve, the film becomes less objective and more mimetic, giving rise to what Gilles Deleuze called the "free indirect discourse" (148) of subjectivity between the audience and the film and between individuals in the audience via the film: " $\mathrm{T}]$ he individual consciousness and the character are captured together and deported into a region where singular life and collective life are confused" (Agamben 22). The limits of film as mediated experience are transcended by the screening of transgressive and transgressed bodies precisely because the body is so visually potent and, thus, affectively powerful. As Lindsay Anne Hallam writes, "everything returns to the body, for all ideas are expressed through and upon it" (217).

In privileging the body as the locus of transgressive potential, the giallo inserts itself into a cultural lineage that includes Christianity and the Marquis de Sade. Unfortunately, from this lineage, the giallo inherits the notion that transgression that originates in the body will necessarily lead to carnality or, at worst, carnage.
When bodily volition exceeds the limits imposed upon it by society, the result is invariably violent sex and even more violent death. In this, the giallo exhibits the opinion that it is the natural will of the human body to rape and kill. ${ }^{8}$ If, as Freud says, "civilization is built upon a renunciation of instinct" (44), then the urge for freedom is actually the desire to act upon instinct unfettered: "The urge for freedom, therefore, is directed against particular forms and demands of civilization or against civilization altogether" (43).

It is no coincidence that the masculine heroes of gialli-symbolic bodyguards of the status

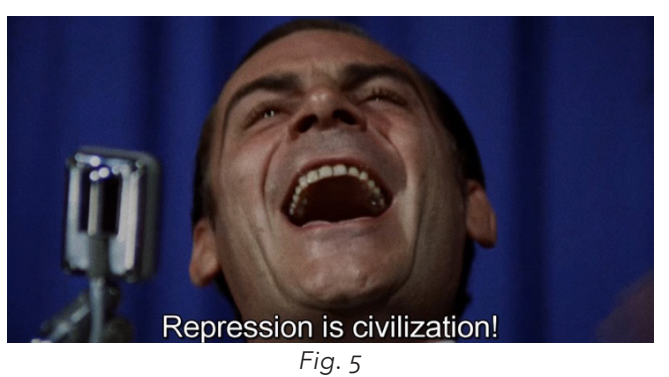

quo-are so often executives, journalists, architects, and doctors: they are men who live the life of the mind, whose prowess is intellectual, not physical. This too echoes Freud: "No feature...seems better to characterize civilization than its esteem and encouragement of man's higher mental activities" (41). Contrarily, characters considered suspect and perverse are those in hot pursuit of earthly delights: pimps, junkies, dope fiends, peeping toms, tramps, hippies, and the like.

Yet the giallo is not blind to the pleasures of transgression. An early scene in Fulci's A Lizard in a Woman's Skin (1971) oscillates between two neighbouring townhouses in London. In one, an upper-class family, surrounded by 
Edwardian regalia, sits in joyless silence as they peck at their dinner. Through the wall from the house next door rumble the sounds of a raging bacchanal: drums pound and guitars squeal as revelers drink, dance, and disrobe. The contrast between grey-faced, chain-smoking bourgeoisie and the vivacious, cavorting libertines is underscored by the cinematography. The wealthy family is primarily captured in static, claustrophobic close-ups, whereas the camera careens handheld through the party, with supple torsos and flailing limbs swimming in and out of focus. When the greying patriarch of the family jokes lamely that the noise next door "sounds like a football match," the camera rushes in to reveal the foot of his teenaged step-granddaughter tapping defiantly along to the hippies' music. Neither wealth, good manners, nor elegant decor can immunize a family from the contagions of Dionysian decadenceor a good beat. Indeed, the giallo does not defend the hegemonic order. In Don't Torture a Duckling (1972), Patrizia represents modernity and its supposed moral contamination, but she is also smart, charismatic, adventuresome, and empathetic. Meanwhile, the supposedly humble and earthy townsfolk engage in prostitution, blackmail, and vigilantism.

The giallo's stubborn ambivalence towards its characters and their actions deprives the audience of moral clarity. Transgression is sexy and exciting but brings with it disorder and death. Hegemony is intolerant and authoritarian, but also reliable and trustworthy. Rather than attempt to reconcile such contradictions, the giallo stages the clash between transgression and hegemony: whichever triumphs is not a question of materials, ethics, or aesthetics but an issue of pure force. The giallo screens a Nietzschean interplay of bodies-and, according to Gilles Deleuze, bodies are themselves "forces, nothing but forces" (139). The interplay of forces does not necessarily imply diametric opposition, nor that they orbit a "natural" point of balance. As Deleuze claims, "Force no longer has a centre precisely because it is inseparable from its relation to other forces" (142), as in a body exercising its force within a sprawling network of interactions.

As a dramatization of the interplay of bodies-as-forces, the giallo is horrific because this interplay irresistibly produces death. Upon the Sadean premise that human nature tends towards excess, exploitation, and dominance, transgression leads to a cycle of ever-escalating violence. Yet hegemony does the same: anything that exists in excess to or defiance of the system must be eliminated. In the giallo, order is only ever provisionally and apparently restored once the killer has themselves been killed. The final satisfaction of either transgression or hegemony is the destruction of the other.

In spite of this, gialli failed to inspire lethal street fights between libertines and reactionaries among its audience. Further, in contrast to the pious pearl-clutching that commonly meets exploitation cinema, the commercial success of gialli did not inspire moral panic in its native Italy. The anticipation of such outcomes rests upon two distinct false assumptions: in the case of the former, that the audience identifies literally with the characters onscreen and will reproduce their ethics and actions in the real world; in the case of the latter, that the films express pre-existing desires and needs on the part of the audience. Against these assumptions, Louis Bayman and Sergio Rigoletto contend that film is neither "an answer to a particular pre-defined need nor as possessing a life of its own, pushing or binding the spectator. 
Film is instead the mid-point in a dynamic interaction between spectator and social context, one which helps construct new needs through the creative invention of emotional experiences that do not pre-exist the viewing of a film" (20). Moreover, so much in gialli is theatrical and anti-naturalistic-from the campy fashions and unlikely mobility of the characters, to the vertiginous zooms and hypersaturated colours - that the films draw attention to their distance from reality, extended by the stylized and often surreal murders (Koven 125). Koven elaborates:

These shocking sequences call attention to themselves...we are jolted out of our cinematic complacency to think not only about "how" such a sequence is made, but "why"... . These sequences, in giallo, are interesting not just because of their shock value, but because they demand we think about the very ontology of the cinema and our pleasures of watching such images. (157)

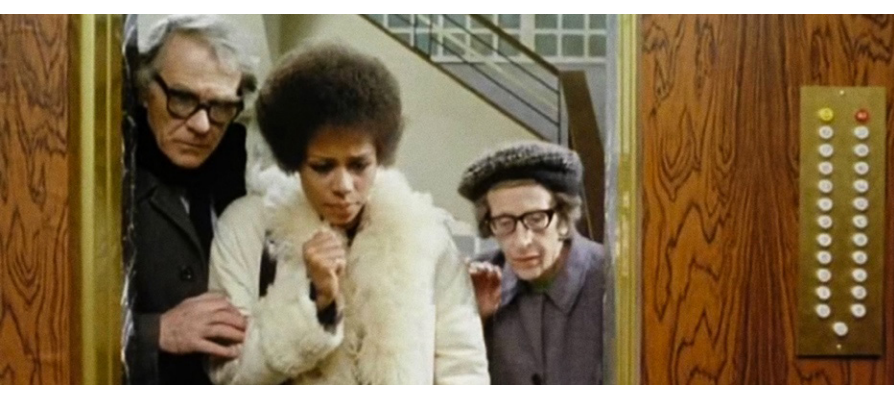

Fig. 6

More specifically, because the giallo focuses upon the violent interplay of transgression and hegemony, it poses a fundamental question: with which do you identify more closely, transgression or hegemony, and why? The answer to this resides in our relation to that which transgression produces: difference. Difference can be regarded as positive or negative. Recall, for example, the heterogenous assembly of tower-block occupants in The Case of the Bloody Iris (1972): is social diversity an opportunity to broaden communal empathy or does dissimilarity weaken security? In other words, is social difference additive or subtractive?

There is no correct answer to that question in the gialli themselves, insofar as the films are open to a choice in interpretation. Yet there are ethical consequences to this choice. To regard difference as bad is to want it subtracted, annulled, exhausted. As depicted in the giallo, it is this drive to annihilate and erase difference that ultimately produces death. However, the opposite choice is also available: to regard difference as good, generative, invigorating-a productive force with which to affiliate, correlate, and integrate. This additive interplay of forces, claims Deleuze, is "the kind which knows how to transform itself, to metamorphose itself according to the forces it encounters, and which forms a constantly larger force with them, always increasing the power to live, always opening new 'possibilities"' (141).

This is why the giallo-a category that could so easily be written off as crypto-reactionary pablum-consistently presents modernization and transgression as seductive and exciting: modernization and transgression are wellsprings of the new; new people, new places, new sensations, new experiences. Death may be inevitable, but it comes much quicker by (and to) those who wish to extinguish the excesses and messy heterogeneity of life. Far better, as Deleuze advises, "to be exhausted by life rather than exhausting it, always... at the service of what is reborn from life, what metamorphoses and creates" (142). 


\section{Works Cited}

Agamben, Giorgio. "For an Ethics of the Cinema." Cinema and Agamben: Ethics, Biopolitics and the Moving Image. Edited by Henrik Gustafsson and Asbjorn Gronstad, Bloomsbury, 2014, pp. 19-24.

Argento, Dario, director. L'uccello dalle piume di cristallo [The Bird with the Crystal Plumage]. Central Cinema Company Film, Glazier, Seda Spettacoli, 1970.

---. 4 mosche di velluto grigio [Four Flies on Grey Velvet]. Marianne Productions, Seda Spetaccoli, Universal Productions France, 1971.

Bava, Lamberto, director. La casa con la scala nel buio [A Blade in the Dark]. National Cinematografica, Nuova Dania Cinematografica, 1983.

Bava, Mario, director. La maschera del demonio [The Mask of Satan; Black Sunday]. Galatea Film, Jolly Film, 1960.

---. La ragazza che sapeva troppo [The Girl Who Knew Too Much]. Galatea Film, Coronet S.r.l., 1963.

---. 6 donne per l'assassino [Blood and Black Lace]. Emmepi Cinematografica, Les Productions Georges de Beauregard, Monachia Film, Arrow Film \& Video, 1964 .

Bayman, Louis and Sergio Rigoletto. "The Fair and the Museum: Framing the Popular." Popular Italian Cinema. Edited by Louis Bayman and Sergio Rigoletto, Palgrave Macmillan, 2013, pp. 1-28.

Bazzoni, Luigi, director. Giornata nera per l'ariete [The Fifth Cord]. B.R.C. Produzione S.r.l., 1971.
Bergonzelli, Sergio, director. Nelle pieghe della carne [In the Folds of the Flesh]. MGB Cinematografica, Talía Films, 1970.

Bianchi, Andrea, director. Nude per l'assassino [Strip Nude for Your Killer]. Fral Spa, Blue Underground, 1975.

Bini, Andrea. "Horror Cinema: The Emancipation of Women and Urban Anxiety." Popular Italian Cinema: Culture and Politics in a Postwar Society. Edited by Flavia Brizio-Skov, I.B. Tauris \& Co., 2011, pp. 53-82.

Burke, Frank. "Dario Argento's The Bird with the Crystal Plumage: Caging Women's Rage." Killing Women: The Visual Culture of Gender and Violence. Edited by Annette Burfoot and Susan Lord, Wilfred Laurier University Press, 2006, pp. 197-217.

Carmineo, Giuliano, director. Perché quelle strane gocce di sangue sul corpo di Jennifer? [The Case of the Bloody Iris]. Galassia Cinematografica, Lea Film, Anchor Bay Entertainment, 1972.

Cixous, Helène. "The Laugh of the Medusa." Translated by Keith Cohen and Paula Cohen. Signs, vol. 1, no. 4,1976 , pp. $875-893$.

Clover, Carol J. Men, Women, and Chain Saws: Gender in the Modern Horror Film. Princeton University Press, 2015.

De Martino, Alberto, director. L'uomo dagli occhi di ghiaccio [The Man with Icy Eyes]. Cinegai S.p.A., 1971.

Deleuze, Gilles. Cinema 2: The Time-Image. Translated by Hugh Tomlinson and Robert Galeta, The University of Minnesota Press, 1989.

Ercoli, Luciano, director. La morte cammina con $i$ tacchi alti [Death Walks on High Heels]. Atlántida Films, Cinecompany, 1971. 
---. La morte accarezza a mezzanotte [Death Walks at Midnight]. Cinecompany, C.B. Films S.A., Mondo Macabro, 1972.

Farina, Corrado, director. Hanno cambiato faccia [They Have Changed Their Face]. Film 70, 1971.

Federici, Silvia. "Why Sexuality Is Work." Revolution at Point Zero: Housework, Reproduction, and Feminist Struggle. Autonomedia, 2012, pp. 23-27.

Foucault, Michel. "A Preface to Transgression." Aesthetics, Method, and Epistemology. Edited by James D. Faubion, translated by Robert Hurley, The New Press, 1998, pp. 69-87.

Frayling, Christopher. Spaghetti Westerns: Cowboys and Europeans from Karl May to Sergio Leone. Routledge \& Kegan Paul, 1981.

Freeland, Cynthia A. The Naked and the Undead: Evil and the Appeal of Horror. Westview Press, 2000.

Freud, Sigmund. Reflections on War and Death. Translated by A.A. Brill and Alfred B. Kuttner, Moffatt, Yard and Company, 1918.

---. Civilization and Its Discontents. Translated by James Strachey, W.W. Norton \& Company Inc., 1962.

Fulci, Lucio, director. Una lucertola con la pelle di donna [A Lizard in a Woman's Skin]. Atlántida Films, Les Films Corona, International Apollo Films, Mondo Macabro, 1971.

---. Non si sevizia un paperino [Don't Torture a Duckling]. Medusa Distribuzione, Blue Underground, 1972.

---. "Lucio Fulci." Spaghetti Nightmares, by Luca M. Palmerini and Gaetano Mistretta, Fantasma Books, 1996, pp. 58-66.
"GialloScore.com-Criteria." GialloScore, http://gialloscore.com/criteria.aspx. Accessed 30 April, 2017.

Glynn, Ruth. Women, Terrorism, and Trauma in Italian Culture. Palgrave Macmillan, 2013.

Gunning, Tom. "An Aesthetic of Astonishment: Early Film and the (In)Credulous Spectator." Film Theory and Criticism, th Edition. Edited by Leo Braudy and Marshall Cohen, Oxford University Press, 2009, pp. 736-750.

Hallam, Lindsay Anne. Screening the Marquis de Sade: Pleasure, Pain and the Transgressive Body in Film. McFarland \& Company, Inc., 2012.

James, Selma. "Introduction." The Power of Women and the Subversion of the Community, by Mariarosa Dalla Costa and Selma James, Falling Wall Press Ltd., 1975, pp. 5-20.

Jenks, Carol. "The other face of death: Barbara Steele and La maschera del demonio." Popular European Cinema. Edited by Richard Dyer and Ginette Vincendeau, Routledge, 1992, pp. 149-162.

Lado, Aldo, director. La corta notte delle bambole di vetro [Short Night of the Glass Dolls]. Dieter Geissler Filmproduktion, Doria G. Film, Dunhill Cinematografia, Jadran Film, Rewind Film, Surf Film, 1971.

---. Chi l'ha visto morire? [Who Saw Her Die?]. Dieter Geissler Filmproduktion, Doria G. Film, Roas Produzioni, 1972.

Koven, Mikel J. La Dolce Morte: Vernacular Cinema and the Italian Giallo Film. The Scarecrow Press, 2006.

Lenzi, Umberto. “Umberto Lenzi." Spaghetti Nightmares, by Luca M. Palmerini and Gaetano Mistretta, Fantasma Books, 1996, pp. 67-72. 
Martino, Sergio, director. Lo strano vizio della Signora Wardh [The Strange Vice of Mrs Wardh]. Copercines, Devon Film, Laurie International, MLR, 1971.

---. Tutti i colori del buio [All the Colors of the Dark]. Lea Cinematografica, National Cinematografica, Astro C.C., Shriek Show, 1972.

---. Il tuo vizio è una stanza chiusa e solo io ne ho la chiave [Your Vice is a Locked Room and Only I Have the Key]. Lea Film, Arrow Films, 1972.

---. I corpi presentano tracce di violenza carnale [Torso]. Compagnia Cinematografica Champion, 1973.

Mendik, Xavier. "The Return of the Rural Repressed: Italian Horror and the Mezzogiorno Giallo." A Companion to the Horror Film. Edited by Harry M. Benshoff, Wiley Blackwell, 2014, pp. 390-405.

Mulvey, Laura. "Visual Pleasure and Narrative Cinema." Visual and Other Pleasures. Palgrave, 1989.

Needham, Gary. "Playing with genre: An introduction to the Italian giallo." Kinoeye, vol. 2, no. 11, 10 June 2002, http://www.kinoeye.org/o2/11/needham11.php. Accessed 23 March 2018.

O'Leary, Alan. Tragedia all'italiana: Italian Cinema and Italian Terrorisms, 1970-2010. Peter Lang, 2011.

Pasolini, Pier Paolo. Heretical Empiricism. Translated by Ben Lawton and Louise K. Barnett, New Academia Publishing, 2005.

Pisters, Patricia. The Matrix of Visual Culture: Working with Deleuze in Film Theory. Stanford University Press, 2003.

Sevastakis, Michael. Giallo Cinema and its Folktale Roots: A Critical Study of 10 Films, 1962-1987. McFarland \& Company, 2016.
Sorlin, Pierre. Italian National Cinema 1896-1996. Routledge, 2001.

Totaro, Donato. "The Italian zombie film: from derivation to invention." Fear Without Frontiers: Horror Cinema Across the Globe. Edited by Steven Jay Schneider, FAB Press, 2003, pp. 161-173.

Wagstaff, Christopher. "A forkful of Westerns: Industry, audiences and the Italian Western." Popular European Cinema. Edited by Richard Dyer and Ginette Vincendeau, Routledge, 1992, pp.245-261.

---. “Italian Cinema, Popular?" Popular Italian Cinema. Edited by Louis Bayman and Sergio Rigoletto, Palgrave Macmillan, 2013, pp.29-51.

\section{Image Notes}

Fig. 1. Bianchi, Andrea, director. Nude per l'assassino [Strip Nude for Your Killer]. Fral Spa, Blue Underground, 1975 .

Fig. 2. Bava, Mario, director. 5 bambole per la luna d'agosto [5 Dolls for an August Moon]. Produzioni Atlas Consorziate (P.A.C.), Arrow Films, 1970.

Fig. 3. Fulci, Lucio, director. Non si sevizia un paperino [Don't Torture a Duckling]. Medusa Distribuzione, Blue Underground, 1972.

Fig. 4. Fulci, Lucio, director. Una lucertola con la pelle di donna [A Lizard in a Woman's Skin]. Atlántida Films, Les Films Corona, International Apollo Films, Mondo Macabro, 1971.

Fig. 5. Petri, Elio, director. Indagine su un cittadino al di sopra di ogni sospetto [Investigation of a Citizen Above Suspicion]. Vera Films S.p.a., The Criterion Collection, 1970. 
Fig. 6. Carmineo, Giuliano, director. Perché quelle strane gocce di sangue sul corpo di Jennifer? [The Case of the Bloody Iris]. Galassia Cinematografica, Lea Film, Anchor Bay Entertainment, 1972.

\section{Notes}

1 "Genre," as conventionally understood in popular Anglophone film criticism, implies a fixity of characteristics that is difficult to maintain in discussions of Italian popular cinema. Better suited here is the Italian critical term is filone (literally "vein" or "current"), suggestive of concurrent streams or threads which mingle or separate arbitrarily.

2 Giallo tropes are so consistent that an online film directory, GialloScore.com, ranks films according points awarded for the presence of various tropes in a given film (black gloves $=5$ points, mistaken identity $=2$ points, bathtub murder $=1$ point ) .

3 "In 1975, first-run cinemas, which made up only one eighth of the total, received half of the total box-office takings" (Sorlin 120).

4 Because of the sheer number of terza visione and the lower cost of distributing films to them, they offered a distinct financial advantage to lower-budget productions that did not need to recoup their costs in a hurry. Such films could tour the tertiary market indefinitely, earning "exceptionally large receipts from terza visione and the provinces over longish periods (four or five years)" (Wagstaff 247).

5 Despite its forced contrast between upwardly-mobile, cosmopolitan Northerners and Southerners trapped in "archaic and feudal modes of existence" (Mendik 395), the Mezzogiorno giallo rarely makes any "serious examination of the social or economic factors that underpin [the Southerners'] malaise" (Mendik 397).
6 This provides an interesting contrast to another 1970 filone, the poliziottesco or crime-thriller. In those films, the protagonist is unvaryingly an ironwilled and brutally effective police officer who refuses to let the law stand in the way of justice. O'Leary understands the poliziottesco as both a screening of and salve for the tensions produced by the political and economic violence of the anni di piombo: "they depict situations pushed to the ne plus ultra which articulate not the reality of contemporary Italian society so much as a fantasy projection of that reality which is part anxiety and (I propose) part wish-fulfilment" (95).

7 The giallo's female killer is something like the obscene symptom of American horror's "final girl": both claim for themselves and perform so-called "masculine" violence, but the giallo's female killer does so pre-emptively and voluntarily, rather than reactively and defensively.

8 This is a gross simplification of Freud, not to mention a conflation of Freud and de Sade. Nonetheless, it is a simplification and conflation made purposefully and explicitly by the giallo. For example, the opening credits of Lo strano vizio della Signora Wardh (1971) end with a title-card featuring the following quote from Freud: "The very emphasis of the commandment: Thou shalt not kill, makes it certain that we are descended from an endlessly long chain of generations of murderers, whose love of murder was in their blood as it is perhaps also in ours" (6o-61). 